\title{
Liner shipping cascading effect on Southern African Development Community port strategies
}

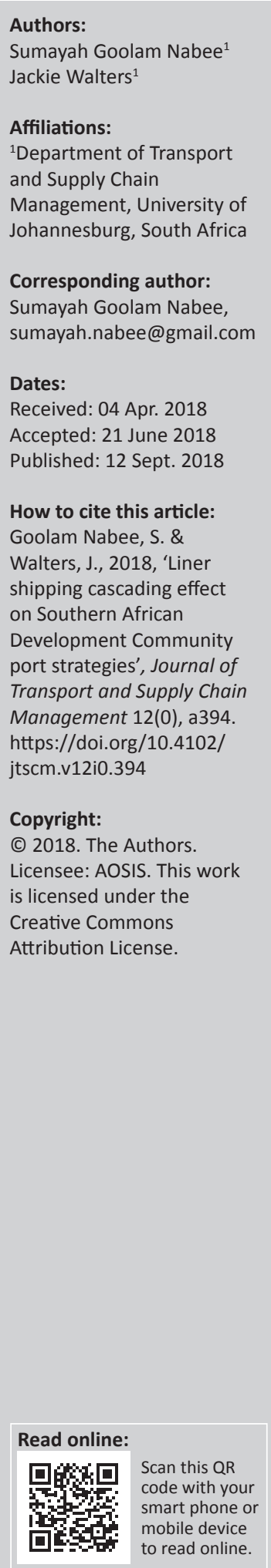

Background: The cascading effect in the liner shipping industry has forced the ply of larger ships to Southern African Development Community (SADC) ports. This requires these ports to revise their strategic development to accommodate the resulting shifts in cargo flows to and from these strategic ports in conjunction with hinterland corridor development.

Objectives: The purpose of this research was to understand the changing landscape of strategic SADC ports and develop future strategies with regard to liner shipping services.

The main objective was to assess the future development needs of the SADC port system in relation to the cascading effect in liner shipping, linked to the development of hinterland corridors, identifying the limitations and opportunities of each port.

Method: Descripto-exploratory research and analysis of secondary data were used. An extensive research of 552 sources (journal articles, research reports, books, newspaper and magazine articles and webpages) dating mostly from the year 2000 onwards were analysed.

Results: Durban will remain the preferred container hub port for the foreseeable future if the port can increase its capacity and offer superior customer service in relation to competing ports in the region, such as Maputo, Walvis Bay and Ngqura. Durban is well adapted to accommodate the port and landside requirements resulting from the cascading effect. This is most evident in the depth of the port and port-side handling equipment. The findings confirm that the success of other SADC ports and corridors are subject to regional cooperation and integration without which the dominance of the port of Durban and the Maputo and North-South corridors will continue.

Conclusion: The findings of the research indicate that Durban is ideally suited to develop further as a container hub port for the SADC region. This development is subject to a more competitive port landscape in the region as other ports such as Maputo, Walvis Bay and Ngqura improve their liner shipping service offering.

\section{Introduction}

The Southern African Development Community (SADC) includes 15 countries and has a population of 257.7 million people with a combined gross domestic product (GDP) of $\$ 471.1$ million (SADC 2012a). Despite many challenges including corruption, fraud and trade barriers, the region expected a 4.2\% GDP growth rate in 2016, while future growth prospects remain positive (Zinyuke 2016).

Trade between African nations and other developing nations are significant. Brazil, Russia, India, China and South Africa (BRICS) represented less than $2 \%$ of world trade in the 1980 s and a modest $4.0 \%$ in 1994, but by 2008, this figure had risen to $20 \%$ (Ballim 2010). While India and Brazil's trade with Africa represents 6.5\% of their global trade (Ballim 2010), in 2014, Africa's trade relationship with China was worth $\$ 200$ billion (Rotberg 2014).

Maritime transport is a key link in international trade and ports are a 'vital aspect of a national transport infrastructure as they link trading partners and act as a major economic multiplier for the nation's prosperity' (Alderton 2008:2). The maritime industry is effective in that it offers an economical and reliable method of transporting goods over long distances, although efficiency is reliant on the provision of adequate infrastructure and hinterland transport arrangements at ports. Most African ports have been built to support colonial needs and are continually categorised as small, poorly equipped, less productive and unprepared for rapidly changing global trade and 
shipping patterns (Gwilliam 2011:181). As world trade patterns change and South-South ${ }^{1}$ trade surges, intra-African trade flows have grown (African Development Bank [AfDB] 2010a:4).

The $4.2 \%$ GDP growth of the SADC region, together with the presence of larger container ships on the East-West ${ }^{2}$ trade route, has highlighted the largely ill-equipped port facilities of the SADC port systems as the cascading effect displaces 'smaller' container ships on secondary North-South ${ }^{3}$ trade routes (Lam \& Hoe 2008; SADC 2012b). Despite various port development strategies and projects, the cascading effect remains a problem for most SADC ports (Nabee 2015:63). Only six ports in the region have sufficient depth, equipment and management to receive post-Panamax ${ }^{4}$ and larger container ships (Nabee 2015:22). Although the majority of container ships cascading into African waters are conventional Panamaxes ${ }^{5}$, some ports remain suboptimal to accommodate these ships and as such the demand for smaller geared vessels continues (Nabee 2015:98). As global shipping lines consolidate, multimodal operation frequency increases and global terminal operators function in African ports, the necessity to modernise ports to accommodate larger container ships and develop regional hubs continues (AfDB 2010a:184).

Limited research has been carried out concerning the liner shipping industry in SADC. Past global research on ports has concentrated on the decision-making process of port users (Lam \& Dai 2012; Tongzon 2002; Wiegmans, van der Hoest \& Notteboom 2008), the decision-making process of port users considering the hinterland as a selection factor (De Langen 2007; Notteboom 2008a), the effect of container ship size on port selection (Davidson 2014a; Widjaja 2012) and factors affecting port selection in Africa (AfDB 2010a; Caschili \& Medda 2013; Notteboom 2008a; OECD 2014; Raballand et al. 2012).

Tongzon $(2002,2008)$ indicated that port selection is driven by the ability of the port to service its customers' needs through port efficiency, good geographical location, low port charges, adequate infrastructure, a wide range of services and connectivity to other ports. Wiegmans et al. (2008) added that port selection decisions are based on rule of thumb, judgement, intuition, creativity and bounded rationality, while Lam and Dai (2012) identified professional experience and knowledge as important factors in port selection.

While De Langen (2007) identified a highly contestable hinterland as a factor for port competition and port selection, Notteboom (2008b) approached the port-hinterland dynamic from the perspective of port authorities, shipping lines, terminal operators, transport operators and logistics service providers. The latter concluded that competition amongst

1.Trade route between Asia and Africa and/or Asia and Latin America.

2.Trade route between Asia and Europe.

3.Trade routes from Europe, Asia and North America, linking with developing countries in the Southern Hemisphere.

4.Container ship size of between 4000 and 5999 TEU ( $20 \mathrm{ft}$ equivalent units).

5.Container ship size of between 3000 and 3999 TEU ports would increasingly be a function of the ability of the port to serve the hinterland.

Davidson (2014a) investigated the global impact of ship-size development and liner alliances on port planning and productivity which has increased the pressure of port terminal performance. Widjaja (2012) concluded that mega container ships have a positive impact on ports in both the short term and long term, and that they further enhance the competitiveness of a port.

The African Development Bank (2010a) researched ports, logistics and trade in Africa and provided a comprehensive insight into the current state of African ports, taking into consideration the development of hinterlands but not the cascading effect. Other studies have considered the establishment of a hub port in the Southern African region by analysing South Africa's ability to fulfil the role (Notteboom 2008a, 2010). In 2012, the World Bank commissioned a study that focused on time spent in sub-Saharan ports and concluded that dwell time was 'a major commercial instrument used to attract cargo and generate revenues' (Raballand et al. 2012:3). From an infrastructure attractiveness index applied to African ports, Caschili and Medda (2013) found a strong relationship between the hinterland and the reputation of the port amongst stakeholders. A report by the International Transport Forum at the Organisation for Economic Co-operation and Development (OECD 2014) focused on the competitiveness of Durban as a port in an emerging market and concluded that although the port is the main gateway port in Africa, it performs suboptimally. The report considered the hinterland linkages of the port as a means of competitiveness.

This research, therefore, assessed the future development needs of the SADC port system in relation to the cascading effect in liner shipping, linked to the development of hinterland corridors, identifying the limitations and opportunities of each port.

The research responds to the need for an overview of the SADC liner shipping industry and the future development of the port hierarchy to accommodate global liner trends.

\section{Trends in the Southern African Development Community liner shipping industry}

McLellan (2006) identified five key liner shipping trends: emerging transport corridors, increasing container trade, increasing size of container ships, trade route container imbalances and formation of strategic alliances. The growth of the SADC region in mineral resource exploitation, intraregional trade and diversification and the advancement of various industrial sectors have prompted the emergence of new transport corridors where spatial development is fundamental (SADC 2012b). Investments not only in port infrastructure but also in corridor infrastructure have 
improved the usage of these corridors. Examples of emerging strategic corridors in the SADC region are corridors such as Beira, Nacala and Walvis Bay which are capturing a larger share of cargoes from the traditionally dominant North-South and Maputo corridors (SADC 2006).

The demand for freight transport services in Africa is evident by the $5.9 \%$ average growth rate forecasted by the year 2040 (NEPAD, African Union \& AfDB 2011). In 2011, the volume of goods transported along West Africa amounted to 7 million metric tons, in East Africa 45 million metric tons and in the Southern African region 240 million metric tons. ${ }^{6}$ Trade volumes in the Southern African region surpass any other region in Africa, representing $47 \%$ of total trade volume (NEPAD et al. 2011:20).

Globally, containerised traffic volumes are increasing at a rate of $2.4 \%$ per annum. This growth is observed against the ever increasing size of container ships and concerns of reduced service frequency, higher peaks in container traffic, greater pressure on cargo-handling operations and rising terminal and operational costs (UNCTAD 2016b:17). Southern Africa accounts for $22 \%$ of total container trade in Africa, surpassed only by North Africa, which accounts for $45 \%$ of this growth owing to the volume of transshipments to the Mediterranean (Transnet 2015:410). The development of containerisation in the SADC region is subject to (1) the effect of piracy on port-calling strategies, (2) the depth of ports and (3) the level of throughput as a growing middle class demands manufactured goods (Nabee 2015:51). As the rate of containerisation continues to grow, pressure on SADC ports will become twofold; port terminals are required to operate at maximum efficiency and intermodal transfers and the integration between transport modes require the highest possible efficiency and effectiveness (CSIR 2007:29). The immediate consequence of larger container ships in the SADC region emphasises the need for cooperative alliances, mergers and acquisitions and joint ventures to attract cargoes to and from the port and hinterland (UNCTAD 2016b).

As shipping lines pursue strategies of economies of scale by increasing the size of their ships, smaller ships (4000-6000 Twenty-foot Equivalent Units [TEUs]) are forced to operate along secondary trade routes. This phenomenon has been dubbed the 'cascading effect' (Lam \& Hoe 2008). In 2009, the largest vessel calling in South African waters was 6742 TEUs (UNCTAD 2009:166). The effect of very large box carriers ${ }^{7}$ (VLBCs) and Post new-Panamax ${ }^{8}$ ships on the main EastWest trade route has cascaded larger container ships into African waters. Consequently, on the Europe-South AfricaAsia route, ships of up to 12500 TEUs are deployed, with the average ship size being 9000 TEUs (Davidson 2014b; Port Finance International 2014).

6.West Africa (ECOWAS), East Africa (COMESA, EAC and IGAD) and Southern Africa (SADC) countries.

7.Container ship size between 6000 and 12000 TEUs

8.Container ship size +12000 TEUs, includes the latest generation ships.
In 2005, the ratio of empty export TEUs to loaded exported TEUs in West Africa was 90 empty to 10 loaded, in East Africa 80 empty to 20 loaded and in Southern Africa 65 empty to 35 loaded. When compared to the Transpacific (30 empty to 70 loaded) or Asia-Europe (40 empty to 60 loaded) routes, container imbalances in Southern Africa are marginally worse (Gwilliam 2011:188). It is generally accepted that on any global trade, container imbalances will occur.

Liner shipping strategies pursue economies of scale by utilising larger container ships (BIMCO 2014). Larger container ships mean fewer port calls and as such, concentrations will result in the emergence of regional hub ports that are supported by smaller feeder ports. To curb competition and control freight rates, the formation of strategic alliances, mergers and acquisitions and vessel sharing agreements between shipping companies are not uncommon (UNCTAD 2016a). In the SADC region, the use of coastal shipping and feeder services, through the formation of liner conferences, is widely acknowledged (SADC 1996).

\section{African port characteristics}

The functioning of ports has 'become the most important logistic link in the production, distribution and consumption chains of economies worldwide' (Sanchez 2006:3). In 2013, it was expected that African container ports will grow on average by $5 \%$ in volume over the following five years (Containerisation International 2013). It was further predicted that Western European container volumes will grow by 1\%, North America by 3\% and Asia by 5\% for the same period. Although South America and Africa indicate growing container capacities, these ports struggle owing to insufficient equipment, berthing facilities and deep drafts for larger container ships (Containerisation International 2013:8).

The most competitive ports are found in Asia, while ports in Africa are still the least efficient in the world owing to the large number of small ports and serious lack of infrastructure. While private sector investment has accelerated the development of African ports, cargo-handling productivity is hampered by the lack of specialised equipment (AfDB 2010b:32; UNCTAD 2009:164).

Ircha (2006:vi) has outlined various attributes of a successful container port and as such, in the SADC region, South African ports are mostly well established and operate according to world standards with sophisticated technologies (Socikwa 2014). Following liner shipping trends and the upsizing of container ships, the South African ports of Durban, Ngqura and Cape Town are currently the only ports in the SADC region that support post-Panamax ships, while Durban and Ngqura are capable of receiving VLBCs (Transnet 2014). Durban is the leading port in the region, consistently performing on par with ports in East Asia and Europe (Raballand et al. 2012). Other ports within the region, such as Maputo, Walvis Bay and more recently, Dar es Salaam, Nacala and Beira, have through various funding initiatives improved the performance of their ports by expanding, 
rehabilitating and maintaining port and other landside infrastructures (Nabee 2015). The major ports in Angola, Luanda and Lobito are strained and are currently undergoing rehabilitation and expansion (Nabee 2015).

Most ports within the SADC region have reached or are nearing capacity and port upgrades have not developed quickly enough to sustain current demand (Ocean Shipping Consultants Ltd 2009). This in turn has led to problems of congestion within the ports, adding to the supply chain costs. The rise of containerisation further exacerbates the congestion problem through inadequate and ageing infrastructure. With the exception of South Africa, sections of the Walvis Bay corridor and more recently the rehabilitation of the Maputo corridor, hinterland connections are poor. Seaports are not integrated with road and rail linkages; road conditions along many corridors are in dire need of rehabilitation and rail transport is mostly deficient and dominated by road transport (AfDB 2010b; Maritime Southern Africa 2011).

\section{Research objective}

The purpose of this research was to identify the limitations of and opportunities for strategic SADC ports with regard to the cascading effect of container ships in the liner shipping industry.

\section{Research methodology}

A secondary data analysis was most appropriate to conduct research on the current trends and issues affecting the SADC liner shipping industry. Analysing secondary data would allow the pooling of different and often contradictory sources of information on SADC ports into one meaningful location. Secondary data were sourced from a large number of sources including 60 published books, 97 research reports, 39 journal articles, 318 newspaper and magazine articles and 38 webpages. By utilising multiple sources of data, insight into the developments in the maritime industry over a longer period was achieved.

The data extracted from these sources were analysed and collated into a comparative matrix. From the matrix, which included the basic and critical criteria, it was possible to analyse and compare the characteristics of major SADC ports and their associated hinterlands.

\section{Results}

\section{Analysis of strategic Southern African Development Community ports}

Of the 11 SADC ports analysed (Table 1), five strategic ports were selected based on their competitive position in relation to major hinterland corridors (as shown in Figure 1) as potential hub ports for the SADC region. These are the ports of Walvis Bay, Dar es Salaam, Maputo, Ngqura and Durban. The port of Ngqura is strategically located on the
South-South-East trade route 9 and while the port is not connected to any major corridor, as a deep-water port which can handle VLBCs, the port was considered as a potential hub port. Although the remaining ports are considered strategic ports, they do not connect to priority corridors in SADC and could therefore not fulfil the role as a potential hub port.

\section{Port performance comparative matrix}

From Ircha's (2006:vi) characteristics of a successful container port, a port characteristic matrix (Table 1) was compiled to compare the performance of each port. These characteristics were broadly grouped into five categories: throughput volumes; productivity and performance; port infrastructure, capacity and facilities; hinterland connections; and valueadded logistics activities.

\section{Throughput volumes}

The ports in the SADC West Countries (Democratic Republic of the Congo, Angola and Namibia) indicate modest throughput rates of cargoes both in terms of tonnage and TEUs (Table 1). Even though Luanda was hindered by the civil war in Angola, the port is still considered 'busy' compared to Walvis Bay, which was largely 'inactive' up to 2007 owing to low market awareness (JICA 2010:23). Lobito has the advantage of serving a greater and more productive hinterland, while Matadi serves mainly its own hinterland. On the east coast (Tanzania and Mozambique), strategic SADC ports are competitive partly owing to the Gulf of Aden, which is a principal passage for ships trading on the main East-West trade route. The high volume of cargo throughput in Maputo is ascribed to the port being used as an alternative or feeder port to the port of Durban (GHK Ltd \& COMESA 2013:98). Nacala and Beira handle a small percentage of containerised cargoes and are well suited for the export of bulk commodities, such as coal and copper. Though Dar es Salaam shows impressive cargo growth, increasing by 90625 TEUs in 2011/2012 year on year (Tanzania Ports Authority 2012:24), SADC Central Countries' ports, located in South Africa, are considered leaders in the container port system. The port of Durban has the highest throughput volumes in the region and this is attributed to the preference of shipping lines to utilise Durban as a hub port (Port Strategy 2014). Cape Town exploits the position of Durban to attract overflow cargo from the port, while $\mathrm{Ngqura}^{10}$ is a growing port complementing the movement of bulk cargoes (Venter 2017).

\section{Productivity and performance}

Significant investments have been made to improve port infrastructure across the region's ports. Despite these investments, the low number of available berthing spaces and the shallow draft of many berths are a recurrent

9.Trade route between Asia and South America, with transshipment occurring in South Africa.

10.The Port of Ngqura is South Africa's newest deep-water transshipment hub located on the east coast, servicing the industrial bulk commodity requirements of the hinterland. 


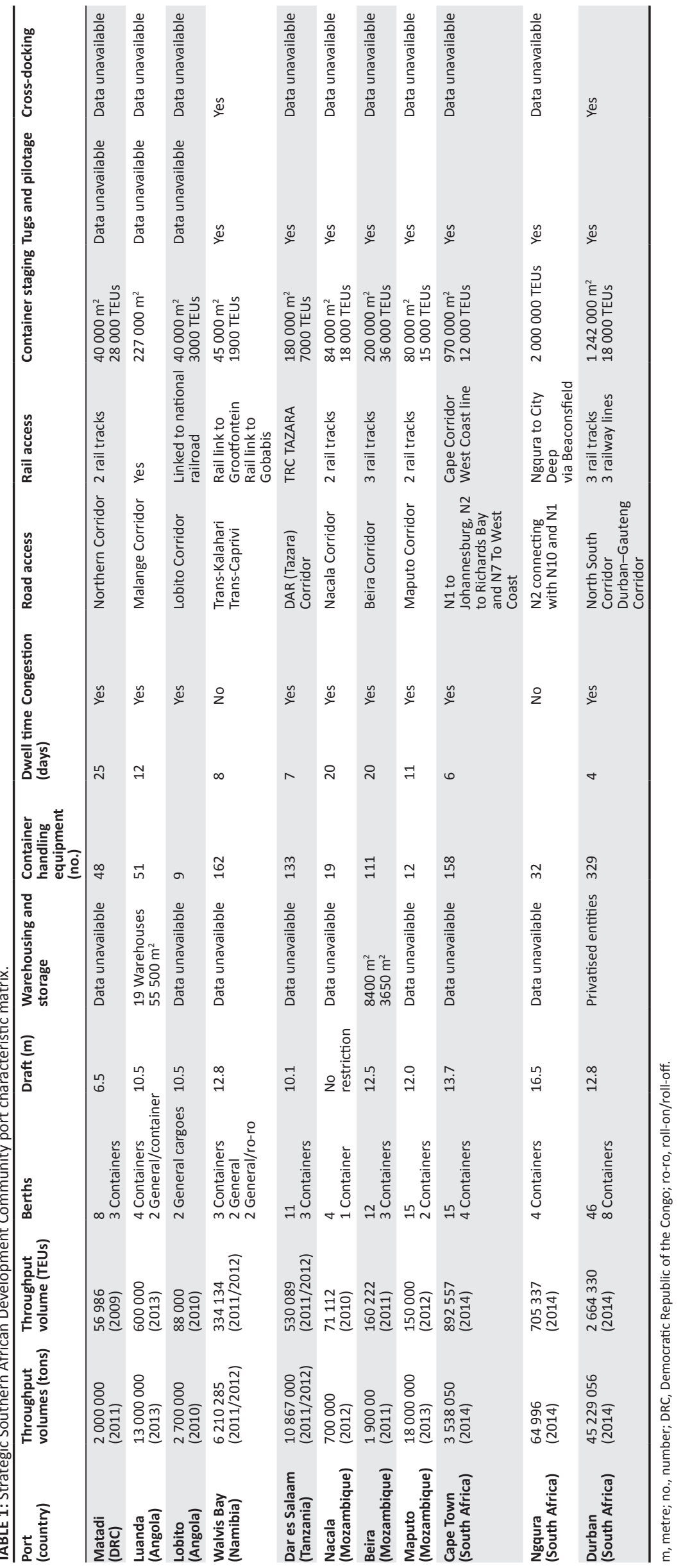




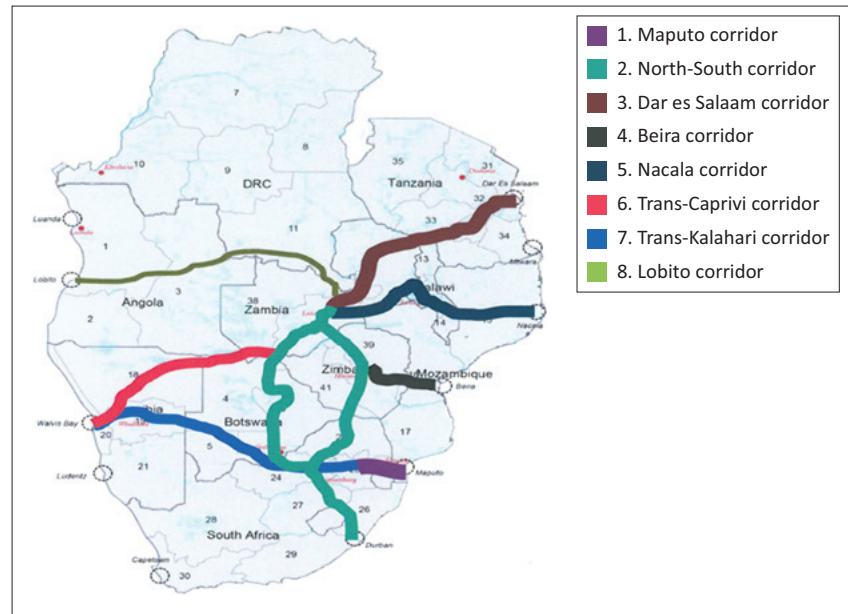

Source: Oikawa, T. \& JICA, 2010. Southern Africa Growth Belt Study - Integrated regional transport program, viewed 01 June 2015, from http://www.afdb.org

FIGURE 1: Strategic Southern African Development Community ports and corresponding corridors.

problem and a deterrent to accommodating larger ships entering SADC waters. The availability of more berths than other SADC ports in Durban contributes to the port's productivity, which is obvious from its low dwell time, the lowest in the region (Raballand et al. 2012). Walvis Bay, owing to its shallow draft, has a maximum container ship capacity of about 5000 TEUs, which is below the average 9000 TEU container ships currently operating on the Europe-South Africa trade route (Port Finance International 2014). At present, only Durban and Ngqura have sufficient depth to accommodate VLBCs.

\section{Port infrastructure, capacity and facilities}

The use of proper port equipment to accommodate the needs of the port varies in the region. Matadi lacks the proper equipment for loading and offloading and can only accommodate geared ships (China Shipping Company 2014). Angolan ports have invested in new cargo-handling equipment, although there is no evidence of the ports having straddle carriers, which are more flexible and productive than rubber tyre gantries (RTG), rail mounted gantries (RMG) or terminal tractors. Walvis Bay has sufficient cargohandling equipment for its current operating needs. Southern African Development Community east countries' ports have a satisfactory range of cargo-handling equipment for the current size of vessels calling on these ports. South African ports have sophisticated cargo-handling equipment such as Mega-Max ship-to-shore gantry cranes ${ }^{11}$ and straddle carriers $^{12}$ which are well suited for the high productivity requirements of VLBCs (Greve 2013; Terminal Investment Limited SA 2012).

\section{Hinterland connections}

Hinterland connections are dominated by the use of road transport in lieu of rail transport. Some of the notable corridors in the region are the Maputo (linked to Maputo

11.Gantry cranes that are capable of loading and unloading container ships that are 25 container rows high and are able to lift containers $46 \mathrm{~m}$ high.

12.Straddle carriers are designed for single and twin lift container operations. port), North-South (linked to Durban port), Beira (linked to Beira port) and Nacala (linked to Nacala port) corridors.

\section{Value-added logistics activities}

From Table 1, it seems that strategic SADC ports are inadequate in the delivery of value-added logistics activities, such as cross-docking services and warehousing. As a port is a link within the greater supply chain network, it is essential to look beyond throughput figures and consider related services. Based on the literature review, only Walvis Bay and the South African ports provide valueadded logistics activities. Container staging is found at all South African ports, while companies such as Grindrod Limited and Kintetsu World Express offer cross-docking services $^{13}$ at the port of Durban (Grindrod Limited 2008; KWE 2013).

\section{The transformation of strategic Southern African Development Community ports}

A detailed strengths, weaknesses, opportunities and threats (SWOT) analysis was conducted for the SADC ports, focusing on the ability to serve the cascading effect of the liner shipping industry.

\section{Port of Walvis Bay (Namibia)}

Namport has stated that the port of Walvis Bay is entering the second phase of development, and this is demonstrated by progress made in terms of port efficiency and the growing competitiveness of the port as an entry to the SADC markets (Ocean Shipping Consultants Ltd 2009:131). Walvis Bay has measured a $54 \%$ increase in commodity movements during the 2011 to 2012 period and is ideally positioned to be a 'gateway' for markets such as the DRC, Zambia, Zimbabwe, Angola and Botswana. The growth in port traffic is not only concentrated on bulk and break-bulk commodities but also on an increasing volume of containers (Odendaal 2013; Trade Ocean 2013). The SWOT analysis of Walvis Bay port is summarised in Table 2.

The development of the Walvis Bay port as a SADC gateway port is initiated by port expansion and infrastructure improvement plans. The new container terminal will serve a multipurpose function including bulk and break-bulk commodities and deeper draft vessels. Where the design of the port is limited to 350000 TEUs per year, this new project will increase the capacity to 650000 TEUs and it is expected to be completed by 2017 (Odendaal 2013). Given the current expansion plans, growth prediction for the port dictates that further capacity will be needed as early as 2019 (AfDB 2013:9).

A bulk fuel storage facility is earmarked for construction and a dry bulk cargo terminal is planned owing to the potential of

\footnotetext{
13. A facility in a supply chain that receives goods from suppliers and then sorts these goods into alternative groupings based on the downstream delivery point. There is no reserve storage of the goods, and staging occurs only for the short periods no reserve storage of the goods, and staging occurs only for the short periods
required to assemble a consolidated, economical load for its immediate onward required to assemble a consolidated, economical load for its immediate onward
carriage via the same mode used for its receipt, or a different mode.
} 
TABLE 2: Strengths, weaknesses, opportunities and threats analysis of Walvis Bay port.

\begin{tabular}{ll}
\hline Analysis & Description \\
\hline Strengths & - Established trading partners \\
- Congestion-free port environment \\
- Value-added logistics services \\
- Strong corridor linkages to Gauteng \\
- Simpler customs procedures \\
- Ship repair facilities \\
- Movement of bulk cargoes from the hinterland and \\
- landlocked neighbouring countries \\
- Positioned on the 'wrong' side of the continent \\
- Cannot accommodate post-Panamax or VLBCs \\
- Limited rail infrastructure \\
- Customs problems at Grootfontein \\
- Cascading effect cannot be sufficiently \\
- accommodated \\
- Benguela rail project in Angola that will assist the port \\
of Luanda in serving a large landlocked hinterland area \\
that could include the countries of Botswana, Zambia, \\
Zimbabwe and Malawi.
\end{tabular}

VLBCs, very large box carriers.

coal cargoes from Botswana (Njini 2013). As far back as 2006, the port was cited as a ship repair facility (Davenport 2006). This is an increasingly viable alternative to similar facilities in Cape Town and Durban.

While the port is expanding to accommodate the cascading effect of larger container ships, the vision for the Walvis Bay port to attain hub port status is somewhat unrealistic as it lies on the wrong side of the continent to take advantage of the growing South-South-East trade (Mathews 2014). In addition, the port is dependent on South Africa to facilitate its exports and imports, accounting for $16 \%$ and $70 \%$, respectively. Other limitations include relatively modest traffic volumes and the preference of cargo owners to use the port of Durban as their gateway (Port Strategy 2014). Studies by Inros Lackner and Nathan Associates indicate that the current expansion plans to increase capacity are 'over and above the needs of the Namibian hinterland and the corridors served' (Maritime Logistics \& Trade Consulting 2013:132). The port will therefore serve niche markets and customers.

\section{Port of Dar es Salaam (Tanzania)}

The port of Dar es Salaam was one of the very first ports in Africa to enter into a public-private partnership (PPP) and this initiative fuelled robust container cargo growth and the demand for additional container capacity (Ocean Shipping Consultants Ltd 2009:173). Although the PPP increased port efficiency and volumes, the port is constrained by container capacity and congestion and this has affected port performance indicators (GHK Ltd \& COMESA 2013:83). The dry port of Kisarawe is an opportunity for the port to reduce congestion, while the refurbishment of the Isaka dry port will further develop the Tanzanian hinterland. Investment initiatives have grown the port as a gateway port serving the needs of Malawi, Zambia, Democratic Republic of the Congo, Burundi, Rwanda and Uganda. Expansion costs are estimated at $\$ 400$ - \$650 million (PWC 2013:78). The SWOT analysis for the port of Dar es Salaam is summarised in Table 3.

The port at Dar es Salaam has lost some business from Congolese and Ugandan customers owing to security issues
TABLE 3: Strengths, weaknesses, opportunities and threats analysis of Dar es Salaam port.

\begin{tabular}{ll}
\hline Analysis & Description \\
\hline Strengths & - Established trading partners \\
Opportunities & - Development of dry ports \\
& - Movement of bulk cargoes from the hinterland and \\
& landlocked neighbouring countries \\
- Congestion and dwell times & Port security issues \\
- Cannot accommodate post-Panamax and VLBCS & - Poor road infrastructure \\
- Inefficient rail system & Cascading effect cannot be sufficiently \\
& accommodated \\
- Port of Beira - alternative for uncleared cargo at Dar es & Salaam port \\
- Development of the port of Bagamoyo (Tanzania) & - Port of Mombassa (Kenya) \\
\hline Threats &
\end{tabular}

VLBCs, very large box carriers.

at the port (GHK Ltd \& COMESA 2013:82). The port is continually threatened by the loss of customers to the port of Beria owing to uncleared cargo. Furthermore, the inefficiencies at the port have cost Tanzania and its neighbouring trading partners to the tune of $\$ 2.6$ billion (Ng'wanakilala 2015). However, forecasts predict that the port will handle $25 \%$ more cargo in 2015 and 28 million tons by 2020, owing to expanded capacities and improved efficiency ( $\mathrm{Ng}^{\prime}$ wanakilala 2015).

Where the port of Mombassa in Kenya is considered a natural transshipment hub for East Africa, the race for hub status becomes more complicated. Mombassa currently handles 800000 TEUs per annum, compared to Dar es Salaam at 530089 TEUs, while the new Tanzanian port Bagamoyo will boast a handling capacity of 20000000 TEUs per annum upon completion (Poverello 2013; PWC 2013:52). On the contrary, Mombassa faces the same challenges as Dar es Salaam capacity constraints and congestion, as well as insufficient rail and road linkages (PWC 2013:52). By 2017, the building and short-term projected operation capabilities of the new Bagamoyo port are likely to affect throughput at Dar es Salaam.

The building of Bagamoyo is not without conflict between the government and potential users of the port. Where shipping agents are currently filling ships up to 2000 TEUs and are forced into mergers to cut operational costs, they are concerned that larger container ship handling at Bagamoyo port is unfounded, based on economic growth and thus state that 'the country will never attract ships of over 6000 TEUs in the coming 25 years' (The Citizen 2015). Unlike Dar es Salaam, Bagamoyo port requires continuous dredging, thereby increasing costs and affecting productivity (Honan 2015). Should the port of Bagamoyo start operations in 2020, the position of Dar es Salaam as the premier port will become secondary. The new port will better serve the cascading effect of larger container ships and threaten the position of the port of Durban, especially in the service of East African countries.

\section{Port of Maputo (Mozambique)}

Within the liner shipping industry, Maputo is ideally positioned to capture hinterland cargoes moving along the Maputo and North-South corridors. The SWOT analysis for the port of Maputo is summarised in Table 4. 
TABLE 4: Strengths, weaknesses, opportunities and threats analysis of Maputo port.

\begin{tabular}{|c|c|}
\hline Analysis & Description \\
\hline Strengths & $\begin{array}{l}\text { - Most successful SADC corridor } \\
\text { - Shortest route from Northern Gauteng } \\
\text { - Established customers } \\
\text { - Good road and rail linkages (on selected routes) } \\
\text { - Shareholders - DP World }\end{array}$ \\
\hline Opportunities & $\begin{array}{l}\text { - Location } \\
\text { - Growth in Mozambican hinterland } \\
\text { - Growth of bulk commodities transiting along the corridor } \\
\text { - Collaboration with the port of Durban }\end{array}$ \\
\hline Weaknesses & $\begin{array}{l}\text { - Cannot accommodate post-Panamax and VLBCs } \\
\text { - Port infrastructure equipment reaching capacity } \\
\text { - Reng dwell times } \\
\text { - line between South Africa and Mozambique) } \\
\text { - Lack of rolling stock } \\
\text { - Road infrastructure - underdeveloped hinterland } \\
\text { - Congestion } \\
\text { - Port - high usage of berths } \\
\text { - Cascadraffic congestion on corridor } \\
\text { - Casfect cannot be sufficiently accommodated }\end{array}$ \\
\hline Threats & $\begin{array}{l}\text { - Proximity to South African ports } \\
\text { - Port of Walvis Bay - Coal from Botswana } \\
\text { - Ports of Beira and Nacala in Mozambique } \\
\text { - Competing local hinterland } \\
\text { The potential development of the new port of } \\
\text { Techobanine, south of Maputo }\end{array}$ \\
\hline
\end{tabular}

SADC, Southern African Development Community; VLBCs, very large box carriers.

A proposed increase from the current 12 metre draft will enable new routes to develop between Maputo and large cargo hubs such as Salalah, Oman (Transport World Africa 2014). South African companies such as SAPPI are moving greater volumes of containerised cargoes through Maputo, while BMW has followed Nissan's example by using both Maputo and Durban ports as exporting bases (Cokayne 2013; Nyathi 2013). Investments by shareholder DP World has significantly improved the performance of the port.

However, the port can only accommodate vessels up to postPanamax size owing to its shallow entry channel. Port infrastructure equipment is reaching capacity and will need to be upgraded or replaced in the near future (Sandhop 2013:77). Furthermore, congestion remains a problem owing to the high usage of the port's two berths and this amplifies dwell times.

As the ports of Beira and Nacala undergo their own improvements, they will become less dependent on Maputo to facilitate hinterland cargo movements. Furthermore, these three ports serve a common hinterland and the deep-water nature of Nacala could see a shift in the short to medium term of both bulk and containerised cargoes.

The Mozambican government has commissioned the building of a deep-water port at Techobanine in the Matutuine district in Maputo. The construction costs are estimated at $\$ 7$ billion and the port is expected to handle 100 million tons of cargo (Trade Bridge Consultants n.d.). It is unclear when the port will be completed as there has been difficulty securing investors, and the proximity of the port and industrial zone to the Isimangaliso World Heritage site poses a 'serious and imminent threat' (Trade Bridge Consultants n.d.; Carnie \& Earth Watch 2012). In terms of the cascading effect, the port of Maputo is responding through the deepening of the draft although traffic volumes and size of the port suggest that it will remain a secondary port to Durban.

\section{Port of Ngqura (South Africa)}

As the newest port in the South African port system, Ngqura was able to capitalise on the latest technology and cargohandling capabilities to position itself favourably in terms of port performance. The port was originally intended as a bulk port although it currently fulfils the role of a transshipment port for East and West African ports as well as inter-continental transshipments. In addition to offering transshipment services for East and West Africa, this role can be extended to serve transit cargoes on the South-South-East trade route. The SWOT analysis for the port of Ngqura is summarised in Table 5.

The port was purposely built to accommodate post-Panamax and VLBCs and currently has no congestion. The 2.2 million TEU capacity of the port is sufficient for current port volumes, although demand forecasts indicate that the port will have to expand to accommodate future volumes and avoid congestion issues (Transnet 2014:177).

The short- and medium-term projections will see the port capture a larger share of the liner trade owing to its deep-water handling capabilities and as such, the port should develop further as a transshipment hub port for South-South-East cargoes. The developments of the ports of Bagamoyo and Techobanine could threaten the position of the port as a transshipment hub.

In the long term, the port will develop as a bulk port, especially for manganese ore operations and crude oil imports and refined fuel exports. For the liner shipping trade, the port is sufficient to accommodate the current cascading effect. Should the Durban dig-out port become a reality, the port could lose its status as a transshipment hub port for South-South-East cargoes.

\section{Port of Durban (South Africa)}

From the SWOT analysis of the port of Durban (Table 6), this port is favoured as the hub port for the SADC region, even internationally. In 2013, it was named as one of the top

TABLE 5: Strengths, weaknesses, opportunities and threats analysis of Ngqura port and its hinterland.

\begin{tabular}{|c|c|}
\hline Analysis & Description \\
\hline Strengths & $\begin{array}{l}\text { - Can accommodate post-Panamax and VLBCs } \\
\text { - Positioned on the South-South-East trade route } \\
\text { - No congestion } \\
\text { - Customers - Automotive industry } \\
\text { - Major international shipping lines - MSC and MOL } \\
\text { - Industrial Development Zone benefits } \\
\text { - Modern port equipment } \\
\text { - Good port productivity } \\
\text { - Cascading effect can be sufficiently accommodated }\end{array}$ \\
\hline Opportunities & $\begin{array}{l}\text { - Secondary gateway for Gauteng } \\
\text { - Port pairing with Luanda } \\
\text { - Growth in bulk commodities } \\
\text { - Transshipment hub port }\end{array}$ \\
\hline Weaknesses & $\begin{array}{l}\text { - Distance from hinterland markets } \\
\text { - No major SADC corridor linked to the port }\end{array}$ \\
\hline Threats & $\begin{array}{l}\text { - New Durban dig-out port that is planned for 2019-2037 } \\
\text { - Port of Bagamoyo (Tanzania) } \\
\text { - Port of Techobanine (Mozambique) }\end{array}$ \\
\hline
\end{tabular}

MSC, Mediterranean Shipping Company; MOL, Mitsui O.S.K. Line; SADC, Southern African Development Community; VLBCs, very large box carriers. 
TABLE 6: Strengths, weaknesses, opportunities and threats analysis of Durban port.

\begin{tabular}{ll}
\hline Analysis & Description \\
\hline Strengths & - East-West trade route \\
- South-South-East trade route & - Biggest port - container capacity in Africa \\
- Favourable dwell time compared to other SADC ports & - Good port infrastructure \\
- Food port productivity \\
- Second highest priority SADC corridor \\
- Good road and rail conditions \\
- Proximity to manufacturing bases \\
- Cascading effect can be sufficiently accommodated \\
- Durban dig-out port \\
- Reduction of freight and logistics costs through improved \\
productivity and efficiency \\
- Support services for East Africa oil and gas reserves \\
- Growth of bulk commodities transiting along corridor \\
- Hub port to the SADC region \\
- Port congestion \\
- Costly port pricing \\
- Hinterland road congestion \\
- Poor utilisation of rail \\
- Competition from other SADC ports \\
- Port of Bagamoyo (Tanzania) \\
- Port of Techobanine (Mozambique) \\
- Competition from other SADC corridors \\
- Economic slowdown of South Africa
\end{tabular}

SADC, Southern African Development Community.

100 ports worldwide and the average cargo dwell time is on par with international standards (Containerisation International 2013; Raballand et al. 2012).

\section{Demand forecasts for Durban port indicate that:}

- Container volumes are set to grow from the current 2.7 million TEUs to 4 million TEUs in 2018 and 12 million TEUs by 2042.

- Automotive volumes will grow to 776000 units over the next 30 years.

- Dry bulk volumes will grow from 9 to 17 million tons.

- Liquid bulk volumes will grow to over 13 million cubic metres over the 30-year period.

- Break-bulk cargoes will likely remain at 2.5 million tons (Motsoahae 2012).

The volume of cargoes moving through the port of Durban is favoured by its feeder route position from the main EastWest shipping trade route. The growing North-South shipping trade route has allowed the port to capitalise on cargoes transiting this route.

While the port has invested in the latest port infrastructure equipment and this has boosted productivity, port congestion and efficiency issues plague the port of Durban. To ease congestion at Durban, the port of Ngqura has off-set some of Durban's traffic, and the port of Cape Town is also used as an alternative port for time-sensitive cargoes.

Although considered a soft issue, the costly structure of port pricing at the port is a matter of concern. The ports of Durban and Cape Town are the most costly, averaging 125\% higher than the global standard (Smith 2015). While many of the reasons for the high costs are external, streamlining the documentation requirements, identifying constraints to port efficiency and cutting the port tariffs should be considered.
The 2050 Vision of the Durban-Gauteng Freight corridor outlines the long-term development of both the port and hinterland infrastructures. The project is set to develop in three phases. The first phase will see the short-term development within the existing port. The second phase will include the new dig-out port on the old airport site. The third phase will be the construction of a new dig-out basin in the Bayhead rail yard (GHK Ltd \& COMESA 2013:119).

The size of the current container terminals and the associated future plans are indicative of the size of the hinterland connection. It is predicted that the current capacity of the existing port will reach its limit by 2019, and therefore the above port development plans are a means of ensuring the economic viability of the port of Durban.

Most recently, the plans of Transnet, the custodian of ports, rail and pipelines in South Africa, to develop a dig-out port in Durban have been delayed and this infrastructure is not likely to be operational by 2020 . Where the current economic growth rate is expected to rise to just 3\% for 2017, it seems likely that this development will take place slower than expected (Greve 2015; Matsilele 2014).

A short-term suboptimal solution is therefore to expand the current harbour. There are other solutions to the congestion problem at Durban, such as developing the PX block some $2 \mathrm{~km}$ from the current port in the Bayhead area for container staging, as well as moving containers away from the terminal to split road traffic and create space at the waterfront, thereby reducing the pressure on road networks (Venter 2014:4).

The oil and gas sector in East Africa represents an opportunity for the port of Durban to provide support services to the industry. The opinion exists that these services should be provided by African shipyards (Maritime Review Southern Africa 2015:2).

The biggest threat for Durban is likely to stem from the port of Bagamoyo. Should this port develop as expected, and yield 20 million TEUs of containers, this figure will outstrip all three South African ports' container handling projections for 2043. As previously indicated, however, the viability of this port is questionable as stated by shipping agents. In the medium term, the port of Techobanine poses some risk to the port of Durban as recent reports indicate plans to reactivate the Techobanine port project (Sunday Standard 2016).

In the long term, Durban will continue to provide a wide range of port and infrastructure operational services. While it is a given that some cargoes may be lost as other SADC ports and hinterlands develop and improve, Durban is expected to remain the port of choice for high-value Gauteng and other inland cargoes. 
The conclusions drawn from the SWOT analysis are as follows:

- The port of Walvis Bay will not develop a threat to the port of Durban as the port lies on the 'wrong' side of the continent, unable to fully capitalise on trade from the South-South-East trade route.

- The current port hierarchy considers the port of Dar es Salaam a competitor for a hub port in the SADC region. However, the building of the new port at Bagamoyo will downgrade Dar es Salaam to a secondary container port in Tanzania. Therefore, the future of Dar es Salaam as a hub port is doubtful.

- The port of Maputo is considered a competitor as a hub port owing to the importance of the Maputo corridor. This is not sufficient, however, as the port cannot handle VLBCs and the close proximity to South African ports entails stiff competition. The proposed building of the new port at Techobanine could force the port of Maputo to become a secondary port in Mozambique. The Maputo corridor could attract cargoes from specific industries, shifting some cargo away from the North-South corridor and the port of Durban. These cargoes are determined to be of a bulk nature.

- The port of Ngqura could potentially serve as a hub port for the SADC although the remoteness of the port to competitive hinterlands such as the Durban-Gauteng corridor will direct the continuing role as a transshipment hub port for South-South-East cargoes.

- The port of Durban remains the most suitable hub port for the SADC region given its sound road and rail linkages. The growth of the South African economy would implement and justify the construction of the new dig-out port and strengthen the overall position of the port.

Currently, the SADC port hierarchy (east coast) is dominated by the ports of Durban, Maputo and Dar es Salaam. Durban as the dominant port both in terms of the volumes handled and the competitiveness of its hinterland is the logical choice for a hub port. The combined container throughput volumes of Maputo and Dar es Salaam combined only account for $25 \%$ of Durban's total container throughput (Nabee 2015:164). Low cargo volumes in the region dictate that cargo is exported mainly through South Africa, using Durban as the primary port. Even as the hierarchy changes, for the foreseeable future, Durban satisfies the requirements as a hub port to accommodate the cascading effect of liner shipping.

\section{Conclusion}

In this research, the findings identified limitations and opportunities for strategic SADC ports with regard to the cascading effect of container ships in the liner shipping industry.

The main objective of the study was therefore to outline future development strategies for SADC ports by evaluating each port's limitations and opportunities against its ability to handle post-Panamax and VLBCs owing to the cascading effect on international liner trade.

The results of the research indicate that although the port of Durban satisfies the requirements for a hub port in the SADC region, the upgrade of other SADC ports and their hinterland access, some cargo movements could shift away from Durban. The most likely cargo shifts could include some bulk products away from Durban to the port of Maputo although the cascading effect will constrain this shift.

Walvis Bay, often used as an alternative port for cargo owners, is well suited to serve the region as a general cargo port rather than a hub port given the restrictions of the cascading effect. In the long-term, the port of Bagamoyo will surpass Dar es Salaam as Tanzania's premier port although politically sensitive issues may halt the development of this port. Maputo will most likely develop as a feeder transit port, supporting activities at the port of Durban.

Ngqura is a prospective hub port; with greater effectiveness, it could serve the SADC market as a transshipment hub port for South-South-East trade.

Durban will remain the preferred container hub port for the region for the foreseeable future. As the most likely hub port, the port must increase its capacity and offer superior customer service to counter the ever increasing competition from other strategic SADC ports. It is clear from Table 1 that most SADC ports cannot effectively participate in the postPanamax and VLBC trend resulting from the cascading effect. South African ports will therefore in the foreseeable future continue to play a leading role as hub ports and transshipment hub ports for smaller container ships servicing both eastern and western ports in SADC.

\section{Future research}

This scope of this research was restricted to strategic container ports in the SADC and potential further research can be applied to general cargo ports to provide an indicative value of this sector to the SADC economy.

The research approach and theoretical framework could be applied to determine or evaluate the potential of secondary SADC ports to develop as feeder ports in the region. Thereafter, a feeder network design framework can be developed, to establish a more efficient maritime transport system for the SADC region.

With the geographic scope of the research limited to the SADC region, future research can establish the impact of the cascading effect and the development of a hub-and-spoke port model for other geographic communities. These communities are identified as the Economic Community of West African States (ECOWAS) and the East African Community (EAC). 


\section{Limitations of the study}

The authors found that the literature presented on the liner shipping industry could be perceived as biased as it originates from port authorities and economic communities. The value of secondary research combined with semi-structured interviews will allow for a 'real-world' view of the liner shipping industry in the SADC, without such bias. Determining the choice of port from the port customer's perspective would most probably carry greater weight as the port authority model develops into public-private partnerships.

\section{Acknowledgements}

The authors would like to thank Prof. J.H. du Plessis for his contribution to this study.

\section{Competing interests}

The authors declare that they have no financial or personal relationships that may have inappropriately influenced them in writing this article.

\section{Authors' contributions}

S.G.N. conducted the research for her master's thesis and coauthored the article. J.W. acted as the supervisor for the master's thesis and co-authored the article.

\section{References}

African Development Bank (AfDB), 2010a, African Development Report 2010: Ports, logistics and trade in Africa, Oxford University Press, New York.

African Development Bank (AfDB), 2010b, 'Port development in Africa', Ports, logistics and trade in Africa, Oxford University Press, New York.

African Development Bank (AfDB), 2013, Project: The new port of Walvis Bay container terminal project, Namibia, viewed 01 September 2015, from http://www.afdb. org/fileadmin/uploads/afdb/Documents/Project-and-Operations/Namibia $\% 20$ - $\% 20$ The $\% 20$ New $\% 20$ Port $\% 20$ of $\% 20$ Walvis $\% 20$ Bay $\% 20$ Container $\% 20$ Terminal\%20Project \%20-\%20Appraisal\%20Report.pdf

Alderton, P.M., 2008, Port management and operations, Informa Law, London.

Ballim, G., 2010, 'Africa's resurgence and the role of BRICS on the Continent', Milken Institute Global Conference: Shaping the future, Milken Institute, Los Angeles, CA viewed 01 April 2014, from http://www.milkeninstitute.org/events/gcprogram.ta f? function=detail\&eventid=GC10\&EvID $=2058$

BIMCO, 2014, Watchkeeper: How big can containerships grow? viewed 04 April 2014 from https://www.bimco.org/news/2014/03/26_watchkeeper_week_13.aspx

Carnie, T. \& Earth Watch, 2012, 'Mozambique harbours ill intent', The Mercury, viewed 01 June 2015, from http://www.iol.co.za/mercury/mozambique-harbours-illintent-1.1303862\#.VhJm3_mqqko

Caschili, S. \& Medda, F., 2013, The port attractiveness index: An application on Africa's ports, viewed 04 April 2014 from https://www.academia.edu/4093316/Port Attractiveness_Index_An_application_on_African_Ports

China Shipping Company, 2014, ICTSI and local partner to develop river terminal a Matadi, viewed 04 April 2014, from http://www.cnshipping.com/en/home/ portsterminalsandlogistics/34591.shtml

Cokayne, R., 2013, 'Grindrod considers further expanding Maputo car depot', Business Report, viewed 01 July 2014, from http://www.iol.co.za/business/companies/ grindrod-considers-further-expanding-maputo-car-depot-1.1573808\#. U9tBqvmSySo

Containerisation International, 2013, 'Steady growth', Containerisation International, viewed 01 May 2014,from http://europe.nxtbook.com/nxteu/informa/ci top100ports2013/

CSIR, 2007, The fourth annual state of logistics survey for South Africa, CSIR, viewed 25 June 2014, from http://www.csir.co.za/sol/docs/SOL_final_CSIR_IL.pdf

Davenport, J., 2006, 'New offshore repair facility at Walvis Bay could spoil Cape Town's repair party', Engineering News, viewed 01 July 2014, from http://www. engineeringnews.co.za/article/new-offshore-repair-facility-at-walvis-bay-couldspoil-cape-towns-repair-party-2006-07-28

Davidson, N., 2014a, 'Global impacts of ship size development and liner alliances on port planning and productivity', IAPH mid-term conference, Sydney, 8th April, viewed 17 February 2015, from http://www.globalmaritimehub.com/reports- presentations/global-impacts-of-ship-size-development-and-liner-alliances-onport-planning-and-productivity.html

Davidson, N., 2014b, Global impacts of ship size development and liner alliances on port planning and productivity, IAPH, Sydney, 8th April, viewed 23 February 2015, from http://iaphsydney2014.com/_data/assets/pdf_file/0017/30581/IAPH_Port_ Planning_and_Investment_-_Neil_Davidson_Drewry.pdf

De Langen, P.W., 2007, Port competition and selection in contestable hinterlands; The case of Austria, viewed 04 April 2014, from http://www.ejtir.tbm.tudelft.nl/ issues/2007_01/pdf/2007_01_01.pdf

GHK Ltd \& COMESA, 2013, South West Indian Ocean maritime corridor scoping study viewed 01 April 2014, from http://www.trademarksa.org/sites/default/files/ publications/TradeMark $\% 20$ SW $\% 2$ Indian $\% 200$ cean $\% 20$ Corridor $\% 20$ FINAL\%20REPORT\%202013-05-20 0.pdf

Greve, N., 2013, 'Cape Town terminal named one of world's top 120 container terminals' Engineering News, viewed 01 April 2014, from http://www.engineeringnews.co.za/ article/cape-town-named-one-of-worlds-top-120-container-terminals-2013-09-16/ article comments: 1

Greve, N., 2015, 'SA GDP growth slows to 1.3\% in Q1', Engineering News, viewed 01 June 2015, from http://www.engineeringnews.co.za/article/sa-gdp-growthslows-to-13-in-q1-2015-05-26

Grindrod Limited, 2008, 'Mitsui and Nissan Dielsel SA award', Making Waves, viewed 01 May 2014, from http://www.grindrod.co.za/uploads/documents/5/making $\% 20$ wavesjan08.pdf

Gwilliam, K., 2011, Africa's transport infrastructure: Mainstreaming maintenance and management, The World Bank, Washington, DC, viewed 26 August 2014 from http://documents.worldbank.org/curated/en/728801468191665263/pdf/60803 OPUBOAfri10Box358332B01PUBLIC1.pdf

Honan, E., 2015, 'Ambitious - Tanzania plans East Africa's biggest port', Business Day Live, viewed21March2015, from http://www.bdlive.co.za/africa/africannews/2015/03/16/ ambitious-tanzania-plans-east-africas-biggest-port

Ircha, M.C., 2006, Characteristics of tomorrow's successful ports, Atlantic Institute for Market Studies, viewed 04 April 2014, from http://www.aims.ca/site/media/ aims/Ircha.pdf

JICA, 2010, Preparatory survey for Southern Africa integrated regional transport program, viewed 01 October 2014, from http://www.mcli.co.za/mcli-web/ downloads/docs/jica-final-report.pdf

KWE, 2013, 'KWE South Africa moves and expands Durban branch and warehouse', News \& Information 2013, viewed 01 May 2015, from http://www.kwe.com/ news/2013/0606.htm

Lam, J.S.L. \& Dai, J., 2012, 'A decision support system for port selection', Transport Planning and Technology 35, 509-524. https://doi.org/10.1080/03081060.2012.6 80822

Lam, L. \& Hoe, O.B., 2008, 'Tomorrow's world', Port Strategy, viewed 23 February 2014, from http://www.portstrategy.com/news101/port-operations/planningand-design/portek_article

Maritime Logistics \& Trade Consulting, 2013, Market study on container terminals in West and Central Africa, viewed 24 June 2014, from http://www.afd.fr/webdav/ shared/ELEMENTS_COMMUNS/pdf/MLTC_CATRAM_market_study_container terminals_West_and_Central_Africa.pdf

Maritime Review Southern Africa, 2015, 'Rigs working off Africa should be serviced in Africa', Maritime Review Southern Africa - Special supplement: Offshore Supporting the African oil and gas sector, viewed 01 October 2015, from http:// issuu.com/maritimereviewsouthernafrica/docs/offshore_supplement $61074 \mathrm{e} 936 \mathrm{f68e} / 1$

Maritime Southern Africa, 2011, The dark continent no more, viewed 24 July 2013, from http://www.maritimesa.co.za/LinkClick.aspx?fileticket=00xyIncv6ck\%3D\&tabid=78

Mathews, C., 2014, 'Freight strategies need priority', Business Day Live, viewed 24 June 2014, from http://www.bdlive.co.za/investorsmonthly/2014/06/10/ freight-strategies-need-priority

Matsilele, T., 2014, 'S. Africa's GDP growth estimated to rise by $1.1 \%$ in 2015', CNBC Africa, viewed 01 June 2015, from http://www.cnbcafrica.com/news/southernafrica/2014/10/22/south-africa-gdp-growth-nene/

McLellan, R., 2006, 'Liner shipping development trends', Maritime Policy \& Management 33, 519-525. https://doi.org/10.1080/03088830601020752

Nabee, S.G., 2015, 'The cascading effect of liner shipping trade on strategic SADC ports', Magister Commercii (Logistics Management) Dissertation, University of Johannesburg.

Motsoahae, P, 2012, 'Presentation to the Public-Private Infrastructure Forum', Public private Infrastructure Forum, 21 June 2012, viewed 20th July 2014, from http:// infrastructurene.ws/wp-content/uploads/sites/4/2012/06/PhumeleleMotsoahae.pdf

NEPAD \& African Union \& AfDB, 2011, Study on Programme for infrastructure development in Africa, viewed 24 June 2014, from http://www.afdb.org/ fileadmin/uploads/afdb/Documents/Project-and-Operations/PIDA\%20Study $\% 20$ Synthesis.pdf

Ng'wanakilala, F., 2015, 'Tanzania's Dar es Salaam port to handle 25 pct more cargo in 2015: President', Reuters Africa, viewed 01 September 2015, from http://af. reuters.com/article/investingNews/idAFKCNOPKORR20150710

Njini, F., 2013, 'Walvis Bay, The SADC gateway', Southern Times, viewed 01 July 2014, from http://www.southerntimesafrica.com/news_article.php?id $=8607 \&$ title $=$ Walvis $\% 20$ Bay $\% 20 \% 20$ the $\% 20$ SADC $\% 20$ gateway\&type $=69 \#$. U9pCL_mSySo

Notteboom, T., 2008a, The development of container terminals in South Africa: Towards a hub for sub-Saharan Africa?, viewed 23 February 2014, from http:// www.kaowarsom.be/documents/B_56_2_2010/05-Notteboom.pdf 
Notteboom, T., 2008b, The relationship between seaports and the intermodal hinterland in light of global supply chains, viewed 20 April 2014, from http://www. internationaltransportforum.org/jtrc/discussionpapers/DP200810.pdf

Notteboom, T., 2010, 'From multi-porting to a hub port configuration: The South African container port system in transition', International Journal of Shipping and Transport Logistics 2, 224-245, viewed 25 February 2014, from http://www.porteconomics. eu/component/docman/doc_download/305-2010ijstlnotteboom.html

Nyathi, S., 2013, 'Sappi's products to be shipped via Maputo port', Fin 24, viewed 01 July 2014, from http://www.fin24.com/Companies/Industrial/Sappisproducts-to-be-shipped-via-Maputo-port-20131216

Ocean Shipping Consultants Ltd, 2009, Beyond the bottlenecks: Ports in Africa, The World Bank, viewed 26 February 2014, from http://infrastructureafrica.org/ system/files/BP08_Ports maintxt_new.pdf

Odendaal, N., 2013, 'NamPort's aim of Walvis Bay port gateway to SADC gains traction', Engineering News, viewed 01 July 2014, from http://www.engineeringnews.co.za/ article/namports-aim-of-walvis-bay-port-gateway-to-sadc-gains-traction-2013-07-02

OECD, 2014, The competitiveness of ports in emerging markets: The case of Durban, SouthAfrica, viewed01 February2015, from http://www.internationaltransportforum. org/Pub/pdf/14Durban.pdf

Oikawa, T. \& JICA, 2010, Southern Africa Growth Belt Study - Integrated regional transport program, viewed 01 June 2015, from http://www.afdb.org

Port Finance International, 2014, 'The potential is just mind-blowing' - PFI conference on African ports, Port Finance International, viewed 14 April 2014, from http:// www.portfinanceinternational.com/features/item $/ 1303-\% \mathrm{E} 2 \% 80 \% 9 \mathrm{Cthe}$ potential-is-just-mind-blowing $\%$ E2\% $\% 0 \% 9 \mathrm{D}$ - $\%$ E2\% $\% 0 \% 93$-pfi-conference-onpotential-is-just
african-ports

Port Strategy, 2014, 'Namibian Dawn', Port Strategy, viewed 01 September 2015, from http://www.portstrategy.com/news101/world/africa/new-era-beckons-forwalvis-bay

Poverello, M., 2013, 'Serious regional competition - China to build Africa's largest port', What happened to the portcullis? viewed 01 June 2015, from http:// mpoverello.com/2013/04/19/serious-regional-competition-china-to-buildafricas-largest-port/

PWC, 2013, Future prospects in Africa for the transportation \& logistics industry: Africa gearing up, viewed 04 April 2014, from https://www.pwc.co.za/en_ZA/za/ assets/pdf/africa-gearing-up.pd

Raballand, G., Refas, S., Beuran, M. \& Isik, G., 2012, Why does cargo spend weeks in sub-Saharan African ports?: Lessons from six countries, viewed 01 April 2014, from http://elibrary.worldbank.org/doi/pdf/10.1596/978-0-8213-9499-1

Rotberg, R., 2014, 'Chinese trade with Africa hits record high', China US Focus, viewed 28 March 2017, from http://www.chinausfocus.com/finance-economy/chinesetrade-with-africa-hits-record-high/

SADC, 1996, Protocol on Transport, communications and meterology, viewed 25 June 2014, from http://www.sadc.int/files/7613/5292/8370/Protocol_on_Transport_ Communications_and_Meteorology_1996.pdf

SADC, 2006, 'Corridors driving infrastructure development', SADC Today, viewed 24 June 2014, from http://www.sardc.net/Editorial/sadctoday/view.asp?vol=352\& pubno=v9n1

SADC, 2012a, SADC overview, viewed 08 May 2014, from http://www.sadc.int/aboutsadc/overview/

SADC, 2012b, Transport corridors and spatial development initiatives, viewed 24 June 2014, from http://www.sadc.int/themes/infrastructure/transport/transportcorridors-spatial-development-initiatives/

Sanchez, R.J., 2006, The role of the new port authorities and the LA port situation, viewed 01 April 2014, from http://www.eclac.cl/drni/noticias/noticias/2/27082/ The_rol.pdf

Sandhop, L.-B., 2013, Economic development and resource boom in Southern Africa: Consequences for port developments in Mozambique, Erasmus University, viewed 01 April 2015, from thesis.eur.nl/pub/14378/BA-thesisLeif-Sandhop-330047-.pdf
Smith, N., 2015, Slow and pricey ports harm business, viewed 01 August 2015, from http://www.bdlive.co.za/economy/2015/07/07/slow-and-pricey-ports-harmbusiness

Socikwa, K. 2014, 'Getting our ports ready for an onslaught of trade', BD Live [Online], viewed 01 June 2014, from http://www.bdlive.co.za/opinion/2014/03/16/ getting-our-ports-ready-for-an-onslaught-of-trade

Sunday Standard, 2016, 'Plans underway to reactivate Techobanine harbour project', The Sunday Standard, viewed 06 March 2018, from http://www.sundaystandard. info/plans-underway-reactivate-techobanine-harbour-project

Tanzania Ports Authority, 2012, Annual Report \& Accounts for the year ended 30th June, 2012, viewed 25 February 2014, from http://www.tanzaniaports.com/ index.php?option=com_docman\&task=cat_view\&gid=48\&ltemid=229

Terminal Investment Limited SA, 2012, Glossary, viewed 01 November 2014, from http://www.tilgroup.com/glossary

The Citizen, 2015, 'Don't build Bagamoyo port, shippers tell govt', The Citizen, viewed 01 July 2015, from http://www.thecitizen.co.tz/magazine/business-week/-/ 01 July 2015, from http://www.thecitize

Tongzon, D.J., 2002, 'Port choice determinants in a competitive environment', Annual conference of the International Association of Maritime Economists, Panama, 13-15 November 2002.

Tongzon, J.L., 2008, 'Port choice and freight forwarders', Transport Research 45, 186-195, viewed 01 November 2014, from http://202.114.89.60/resource/ pdf/1850.pdf

Trade Bridge Consultants, n.d., Deep water port to be built at Techobanine, viewed 15 June 2015, from http://tradebridgeconsultants.com/news/government/deepwater-port-to-be-built-at-techobanine/

Trade Ocean, 2013, Business is booming via Walvis Bay Corridors, viewed 01 May 2014, from http://www.tradeocean.co.za/blog/general-news/walvis-bay-corridors/

Transnet, 2014, Port development plan, viewed 01 April 2014, from http://www. transnet.net/BusinessWithUs/LTPF\%202012/1.LTPF\%202014_Chapter\%2004_ Ports_Final\%20Proof_Sept $\% 202014$.pdf

Transnet, 2015, Africa transport infrastructure planning, viewed 06 February 2017, from http://www.transnet.net/BusinessWithUs/LTPF\%202015/7 LTPF\%202015 Africa_19\%20Aug_LR.pdf

Transport World Africa, 2014, 'Ships of up to 80,000 tons at Port of Maputo', Transport World Africa, viewed 01 July 2014, from http://www.transportworldafrica.co. za/2014/05/20/ships-of-up-to-80000-tons-at-port-of-maputo/

UNCTAD, 2009, Review of Maritime Transport 2009, viewed 04 April 2014, from http://unctad.org/en/docs/rmt2009_en.pdf

UNCTAD, 2016a, Liner shipping: Is there a way for more competition?, viewed 01 July 2017, from http://unctad.org/en/PublicationsLibrary/osgdp2016d1_en.pdf

UNCTAD, 2016b, Review of Maritime Transport 2016, United Nations Publications, viewed 06 February 2017, from http://unctad.org/en/PublicationsLibrary/ rmt2016_en.pdf

Venter, L., 2014, 'To dig out or not to dig out', Freight and Trading Weekly, viewed 01 September 2015, from http://cdn.nowmedia.co.za/NowMedia/ebrochures/ 01 September 2015, from http://cdn.nowmed

Venter, L., 2017, 'Durban congestion hits CT schedules', FTW Online, viewed 03 April 2018, from http://storage.news.nowmedia.co.za/medialibrary/Feature/6362/ FTW-8-September-2017.pdf

Widjaja, L., 2012, Mega container ships: Implications to Port of Singapore, City University London, TU Delft, the Netherlands.

Wiegmans, B.W., van der Hoest, A. \& Notteboom, T., 2008, 'Port and terminal selection by deep-sea container operators', Maritime Policy \& Management 35, 517-534. https://doi.org/10.1080/03088830802469329

Zinyuke, R., 2016, 'SADC economies set for a comeback in 2016', The Southern Times, viewed 01 June 2017, from https://southernafrican.news/2016/01/20/sadceconomies-set-for-a-comeback-in-2016/ 